\title{
Investments in material efficiency: the introduction and application of a comprehensive cost-benefit framework
}

\author{
Florian Flachenecker ${ }^{*}$, Raimund Bleischwitz ${ }^{*}$ Jun E. Rentschler ${ }^{*+}$ \\ * University College London, Institute for Sustainable Resources, London, UK \\ ${ }^{+}$Oxford Institute for Energy Studies, Oxford, UK
}

\begin{abstract}
Increasing material efficiency is considered to yield multiple economic and environmental benefits. This paper firstly introduces a comprehensive cost-benefit framework to systematically assess the viability of investments in material efficiency. The framework comprises several components by (i) comparing a business-as-usual scenario with a scenario of scaling up investments in material efficiency, (ii) covering economic and environmental dimensions, and (iii) considering direct and indirect effects. In a second step, we match the framework to existing evidence from the literature, followed by an application of the framework to a microeconomic investment project financed by a multilateral development bank. Our results suggest that material efficiency investments can yield positive net benefits, which typically increase when non-monetary dimensions are additionally taken into account. Overall, our analysis calls for a more comprehensive approach towards material efficiency investment appraisals, the internalisation of externalities and further empirical research to better understand the implications of moving towards material efficient economies.
\end{abstract}

Keywords: competitiveness; cost-benefit analysis; investments; material efficiency JEL codes: L60; O31; O33; Q38; Q56

\section{Acknowledgements}

The authors would like to thank Nigel Jollands for his support and contributions to this paper. The helpful comments and suggestions by the editor and two anonymous reviewers significantly improved the quality of the paper. All remaining errors are entirely those of the authors.

Corresponding author: Florian Flachenecker, Institute for Sustainable Resource, Central House, 14 Upper Woburn Place, London WC1H 0NN, United Kingdom.

E-mail: florian.flachenecker.13@ucl.ac.uk 


\section{Introduction}

Given increasing volatile material prices, uncertain supply prospects, reindustrialisation attempts and environmental pressures associated with material use, the concept of material efficiency has gained increasing significance for researcher, policy makers, firms and investors. Material efficiency is seen as one possibility to address these issues and deliver multiple economic and environmental benefits.

The concept of material efficiency is heterogeneously defined across disciplines. From an economics perspective, (technical) efficiency compares a given input-output combination to the optimal one (i.e. maximising output for a given input or minimising input for a given output) (Fried et al. 2008). The optimal combination depends on the theoretical concept of a production possibility frontier and includes costs. Data on such a frontier is either not available or complex to estimate. Thus in practice, material productivity is taken as a proxy for material efficiency (OECD 2001), as the data on productivity is available and increasing productivity essentially results in getting closer to efficiency (even if efficiency is unknown).

Theoretically, economic agents have an incentive to increase their material efficiency if the relative prices for materials are higher compared to other inputs. At first sight, material prices are still above their levels in the in the 1980s and 1990s (IMF 2015) and have become increasingly volatile (Valiante and Egenhofer 2013), and fiscal reform programmes have tended to focus on reducing labour costs (Bleischwitz 2010), all providing an incentive to increase material efficiency. Nevertheless, a substantial material productivity gap prevails across countries, even after accounting for heterogeneous economic structures (Flachenecker and Rentschler 2015). This raises the question whether material efficiency investments indeed yield positive net benefits. Hence, this paper introduces a comprehensive cost-benefit framework to evaluate the viability of material efficiency investments.

The remainder of the paper is structured as follows: Section 2 introduces the comprehensive cost-benefit framework. Section 3 matches the framework to empirical evidence from the existing literature. Section 4 applies the framework to a microeconomic investment project. Section 5 discusses our results, their underlying assumptions and implications. Section 6 concludes.

\section{Introducing a comprehensive cost-benefit framework}

Conventional cost-benefit analyses predominantly consider primary economic (i.e. monetary effects borne by, for instance, firms) implications of investments. Given the particular nature of material efficiency investments, it is essential to additionally take environmental (i.e. externalities), non-market and secondary results into account in order to derive the social costs and benefits of such investments, which are the sum of economic and environmental impacts. Once a monetary value is attributed to those costs and benefits without market prices, this framework allows to calculate the social net benefits of material efficiency investments (OECD 2008). In order to assess social costs and benefits associated with material efficiency, two scenarios are considered:

(i) In the business-as-usual scenario (BAU) maintaining the current (positive) rate of investments is assumed. This scenario considers the costs and benefits from 'inaction'.

(ii) In the scenario of scaling up material efficiency, firms and governments heavily invest in efficiency improvements.

For both scenarios, primary and secondary effects are considered (Cellini and Kee 2010). Primary effects are closely related to the investments main objectives (i.e. direct investments). Secondary effects include indirect effects (i.e. second round), multiplier, 
spillovers, and co-benefits/co-costs (i.e. by-products). Going forward, this framework's scenarios, effects and dimensions are matched to empirical evidence in the existing literature and applied to an investment project.

Table 1 illustrates the comprehensive cost-benefit framework as well as summarises costs and benefits, which are found in the literature and discussed in the next section.

\section{Costs and benefits of investments in material efficiency}

\begin{tabular}{|c|c|c|c|c|}
\hline & \multicolumn{2}{|c|}{ Benefits } & \multicolumn{2}{|c|}{ Costs } \\
\hline & Environmental & Economic & Environmental & Economic \\
\hline 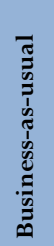 & & $\begin{array}{l}\text { No initial (and follow-up) } \\
\text { investments costs } \\
\text { Lower compliance costs of } \\
\text { environmental regulation }\end{array}$ & $\begin{array}{l}\text { Environmental pressures } \\
\text { (negative externalities) } \\
\text { Reduced human \& natural } \\
\text { capital }\end{array}$ & $\begin{array}{l}\text { Micro costs (e.g. exposure to } \\
\text { volatility) } \\
\text { Macro costs (e.g. import } \\
\text { dependency) } \\
\text { Lock-ins } \\
\text { Supply-chain externalities }\end{array}$ \\
\hline 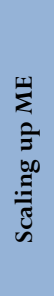 & $\begin{array}{l}\text { Reduced environmental } \\
\text { pressures (negative } \\
\text { externalities) } \\
\text { Reduced negative impacts on } \\
\text { human \& natural capital }\end{array}$ & $\begin{array}{l}\text { Hedging against material } \\
\text { price volatility } \\
\text { Improved micro and macro } \\
\text { competitiveness } \\
\text { Eco-innovation activity } \\
\text { Reduced env. and social } \\
\text { liability (i.e. improved } \\
\text { corporate image) }\end{array}$ & $\begin{array}{l}\text { Positive relationship between } \\
\text { the intensity of exploitation } \\
\text { and environmental impacts } \\
\text { Rebound effect }\end{array}$ & $\begin{array}{l}\text { Initial investment and } \\
\text { maintenance costs (incl. } \\
\text { transaction costs) } \\
\text { Opportunity costs }\end{array}$ \\
\hline
\end{tabular}

Table 1 summarises primary and secondary costs and benefits from material efficiency investments. The framework distinguishes between two scenarios (business-as-usual and scaling up material efficiency) and two dimensions (environmental and economic).

\section{Matching the framework to the existing literature}

\subsection{Environmental costs in the BAU scenario}

(i) Environmental pressures: Materials are referred to as "important intermediaries of environmental impact" (UNEP IRP 2010). Impacts associated with material use can therefore be considered a proxy for environmental costs. Such costs arise in each stage of the life cycle, such as emitting particulates (e.g. dust), erosion from mining, and leakages of chemicals used in the separation process into the environment (UNEP IRP 2010). These costs can occur both at the local and the global level. In the EU-25, the manufacturing industry accounts for $27 \%$ of all direct emissions of greenhouse gases, $27 \%$ of all direct emissions of ground-level ozone precursor gases, and 15\% of direct emissions of acidifying gases (EEA 2013). According to the International Energy Agency, $77 \%$ of the total direct $\mathrm{CO}_{2}$ industrial emissions are due to the production of four materials, namely iron and steel, cement, pulp and paper, and aluminium (IEA 2010). Environmental impacts are often related to negative externalities arising from any forms of waste. For instance, the greenhouse gas methane is emitted from landfills and thus not only negatively impacts the environment locally, but also globally by contributing to climate change (IPCC 2007).

(ii) Secondary costs on human and environmental capital: Environmental costs of using materials inefficiently can also negatively impact economic activity directly and 
indirectly (UNEP 2014), such as negative impacts on human health reducing labour productivity.

Furthermore, it is crucial to take the concept of irreversibility of environmental functions into account (infinitely high cost). Once the environment is harmed beyond a certain threshold, it is unlikely to recover its functions, which calls for the precautionary principle (i.e. safe minimum standard) (Bishop 1978).

\subsection{Environmental benefits in the BAU scenario}

There are no apparent environmental benefits in the BAU scenario.

\subsection{Environmental costs from investments in material efficiency}

Increasing material efficiency could theoretically increase environmental pressures, at least relative to output. For instance, assuming a positive relationship between the intensity of exploitation and environmental pressures (e.g. a grinder could in theory use more energy at its capacity limit relative to its output compared to its energy use per output below this limit) ultimately outweighing the productivity gains. However, there is little evidence suggesting such a non-linear relationship in practice.

Moreover, a potential rebound effect could counterbalance efficiency gains. Generally, the literature distinguishes between two possible outcomes: (i) partially offsetting efficiency gains by increasing consumption (i.e. reducing benefits) and (ii) outweighing such gains altogether (backfire or Jevons' Paradox) (Sorrell 2007). Only (ii) entails costs from an environmental perspective. There has been a lack of attention to the rebound effect of materials compared to energy, because it is thought to be of lower relevance. The consumption of construction minerals (Bahn-Walkowiak et al. 2012) and biomass (Steinberger et al. 2010), both accounting for $69 \%$ of global extraction, is considered to be inelastic and thus the risk of a rebound effect is relatively low. A more recent and sophisticated attempt to quantify the macroeconomic rebound effects of materials suggests that the effects are mostly within single digit percentages (Pfaff and Sartorius 2015).

\subsection{Environmental benefits from investments in material efficiency}

In the absence of a 'backfiring' rebound effect and ceteris paribus, ex post increasing material efficiency results in a relatively lower use of materials. On average, a lower use of materials implies relatively fewer negative impacts on the environment, both locally and globally (Barrett and Scott 2012). Realising numerous material savings opportunities (in terms of environmentally weighted material consumption) of three sectors in the EU-27 (food and drink manufacturing, fabricated metal products, and hospitality and food services) could reduce $2-4 \%$ of total annual EU-wide GHG emissions (AMEC and Bio IS 2013). For the UK, a variety of efficiency improvements could reduce up to $13 \%$ of its total annual GHG emissions (Oakdene Hollins 2011).

Especially through recycling, the environmentally harmful first stages of the materials' life cycles (i.e. extraction, production) can be substituted by using secondary material (Ignatenko et al. 2008; Allwood et al. 2010). This entails lower direct (i.e. less primary production and less waste) and indirect (i.e. lower energy use) negative externalities. For example, secondary production reduces energy use by $55 \%$ for lead and $98 \%$ for palladium (UNEP IRP 2013, p.93). Metals are particularly promising when it comes to recycling, as their recyclability is (theoretically) indefinitely possible (Graedel et al. 2011). 


\subsection{Economic costs in the BAU scenario}

(i) Microeconomic perspective: Material price volatility is an important cause of investment uncertainty (Chatham House 2012) and can take effect, both ex ante and ex post of investing. Ex ante, such uncertainty results in a premium, which firms have to account for in form of higher discount rates and hedging costs (e.g. longterm contracts, capacity building to be engaged in financial markets, or direct ownership of suppliers). Ex post, price fluctuations can impose costs (or benefits) once the outcome deviates from the expected returns (Pindyck 1991). If volatile prices are not hedged, production costs become volatile as well, which in a worstcase scenario can lead to insolvency.

(ii) Macroeconomic perspective: If a country is a net material importer, not increasing efficiency and thus not reducing material imports (e.g. by substituting material imports with domestically sourced secondary raw materials) implies that the dependency on material imports is not mitigated to the extent possible. Persisting dependency can impose significant costs once negative impacts generated by volatile prices unfold (e.g. investment uncertainty, fluctuating subsidy costs) (IMF 2013). Additionally, relying on material imports could result in costs once material trade becomes disrupted by political conflicts. An insecure access to affordable materials might (at least in the short term) become an obstacle to economic growth (Meadows et al. 1972).

(iii) Lock-ins: Lock-ins can cause inefficiencies, and vice versa. Lock-ins describe a situation in which a technology prevails due to economies of scale, network and learning effects even if it is sub-optimal or inefficient (Arthur 1989). For instance, if steel producers have substantially invested into inefficient technology previously, they may be unable to invest into more modern efficient technology due to financial constraints - i.e. they are locked in (Allwood et al. 2011). There are also behavioural and organisational lock-ins (Barnes et al. 2004). Such lock-ins can cause economic costs and also barriers for investments in more efficient technologies (EC 2011a; EC 2011b).

(iv) Supply chain externalities: There are supply-chain externalities from material inefficiency if for instance the design of a product of one firm influences the recyclability of that material by another firm downstream. Multi-layer packaging cannot always be recycled mechanically and producing multi-coloured glass bottles results in increasing recovery costs (Nicolli et al. 2012). The problem is that recycling firms often struggle to provide economic incentives for upstream firms to increase the recyclability of products (Calcott and Walls 2005). Therefore, firmlevel interactions across supply-chains are crucial in improving material efficiency (Schliephake et al. 2009).

\subsection{Economic benefits in the $B A U$ scenario}

Firms can avoid potentially high up-front costs of investing in material efficiency. However, not all efficiency improvements require financial capital, but changing practises, behaviour and organisational structures. Not investing financial capital in efficiency improvements unlocks capital to be invested in potentially more profitable and less uncertain alternatives (Bruyn et al. 2009).

Changing the status quo through expanding monitoring, reporting and compliance with environmental standards will most likely increase costs, which can be avoided in a BAU scenario. 


\subsection{Economic costs from investments in material efficiency}

(i) Initial investment costs: Material efficiency investments typically generate annual income streams (i.e. material savings, higher quality products), but the initial investment might be substantial, disincentivising the investment taking place (AMEC and Bio IS 2013). While the up-front costs are mostly known, the returns may be uncertain and distant in time, especially if material prices are volatile (Ebrahim et al. 2014). If firms are risk averse, they are less likely to invest as they give a relatively lower probability to the expected net present value (NPV) or increase the discount rate (Perman et al. 2011). Investing in material efficiency also triggers operation, maintenance and more generally transaction costs. Such costs can take the form of capacity building (e.g. training) and financing the investment (i.e. searching costs).

(ii) Opportunity costs: Firms only have an incentive to invest in material efficiency if no other feasible alternative offers a higher benefit. One alternative could be substituting materials with other inputs, but this might not always be possible (e.g. rare earth metals). Where substitution is possible, increasing labour productivity for instance might be more beneficial (Bruyn et al. 2009). In the past, productivity has increased by $140 \%$ for labour and by $90 \%$ for materials in the EU-15 between 1970-2007, which could suggest that conventional tax regimes have made labour relatively more expensive and thus incentivised investments in labour over material (Bleischwitz 2012). Bleischwitz (2012) also points to structural changes towards service economies and shifts in imports as possible explanations.

\subsection{Economic benefits from investments in material efficiency}

(i) Reducing uncertainty: This is particularly relevant for material importing economies and material purchasing firms, as increasing efficiency ceteris paribus results in fewer purchases. Lowering material imports through efficiency gains by increasing domestically sourced secondary raw materials would decreases dependency, increase the bargaining power (ECSIP Consortium 2013) and improve the balance of trade (Schmidt and Schneider 2010). Moreover, price fluctuations would have a relatively lower (negative) effect on the economy and firms - one form of hedging against price volatility (Ebrahim et al. 2014).

(ii) Improving competitiveness: At the macroeconomic level, increased material efficiency may strengthen competitiveness, by generally stabilising the macroeconomic environment. For instance, Distelkamp et al. (2010) model various effects of doubling material efficiency in the German economy by 2030. They show positive effects for GDP $(+14 \%)$ and employment $(+1.9 \%)$, and a reduction of material consumption $\left(\right.$ TMR $\left.^{1}-20 \%\right)$ and the public debt $(-11 \%)$. Such effects are the upper threshold and can therefore be interpreted as the maximum potential for efficiency gains. An EU-wide study shows similar positive macroeconomic impacts of resource efficiency improvements until 2030 such as a reduction of resource use by $17-25 \%$ (compared to a baseline scenario), increase in real GDP between 2 and 3.3\% and real labour income combined with a creation of up to 2.6 million jobs (Meyer 2011). ${ }^{2}$

\footnotetext{
${ }^{1}$ Total Material Requirements (TMR) is a material indicator that includes all unused materials and indirect material flows across the supply-chain. For an overview of material indicators, refer to Bringezu (2013).

${ }^{2}$ The evidence provided does not necessarily imply an increase in competitiveness since this also depends on the response from competitors. However, a favourable macroeconomic environment could be considered as a proxy for competitiveness. Evidence on a direct impact of resource efficiency on competitiveness is inconclusive (Flachenecker 2015).
} 
At the firm level, surveys of EU-SMEs reveal a generally positive attitude towards efficiency improvements. Competitiveness gains for firms could result from lowering negative impacts of material price volatility, lowering production costs, increasing innovative activity, and an increased corporate image (Flachenecker 2015). A report considers the benefits from efficiency measures by EU-27 firms across four sectors (AMEC and Bio IS 2013). They suggest that the average net benefit (after subtracting the investments costs) for firms is between $10 \%$ and $17 \%$ of annual turnover. This accounts for $€ 27,500-€ 424,000$ reflecting heterogeneous firm sectors and sizes. Figure 1 provides evidence for EU-SMEs for increased competitiveness through reducing their production costs once a resource efficiency investment has been taken. Such investments for about two-thirds of SMEs in the EU-28 are equal or lower than 5\% of their annual turnover (EC 2013).

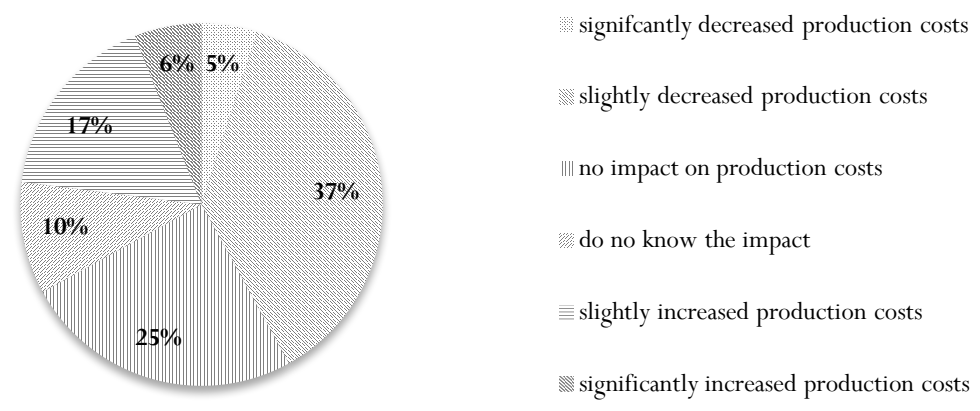

Figure 1 shows the impact of investments in resource efficiency on production costs of 10,511 SMEs in the EU-28, which took at least one resource efficiency action. The question asked: "What impact have the undertaken resource efficiency actions had on the production costs over the past two years?". Source: (EC 2013).

Reducing production costs for firms is particularly important when it comes to materials, since materials constitute a relatively high share of total costs. Material costs in purchasing costs as percentage of gross production value account for $45.3 \%$ for the German manufacturing industry (KfW 2009; Statistisches Bundesamt 2011). For the automobile and machinery sector, materials account for more than 50\%. On EU-level, material costs account for similar levels based on surveys (EC 2011c). For more than half of the EU-27 companies, material costs make up more than $30 \%$ of their overall expenses. Surveys may not coherently account for material costs across all countries and sectors, as they could reflect subjective definitions of materials. The reported materials costs include the cost of the raw materials as well as upstream labour, transportation and storage costs (Wilting and Hanemaaijer 2014).

Additional evidence suggests payback periods for material efficiency measures of less than six months. Average savings have been estimated in the order $7-8 \%$ of material costs for German SMEs in the manufacturing sector (Fh-ISI et al. 2005; Schröter et al. 2011). Most of such cost saving potentials do not pertain to direct material purchasing costs, but rather to hidden costs (i.e. disposal, transportation, production, energy, etc.) (Schmidt and Schneider 2010). For the UK it was estimated that resource efficiency improvements can enable firms to realise cost savings amounting to GBP 23 billion in 2009 (GBP 18 billion for waste prevention) with pay-back periods of less than 12 months (Oakdene Hollins 2011; OECD 2011). 
(iii) Increased innovation: Positive macroeconomic effects of material efficiency innovations on growth, employment and competitiveness are particularly pronounced if first-mover advantages can be established (Walz 2011). Early adopters enjoy an additional cost advantage over their competitors until the innovation is being diffused throughout the market. These profits can trigger further investments, thereby potentially generating additional spillover effects and initiating a virtuous circle, which has been demonstrated in economic models e.g. for the EU and Germany (Meyer 2011).

(iv) Reducing liability: As environmental concerns gain increasing importance, it is likely that environmental regulation will become stricter in the future. Surveys suggest that firms anticipate future changes in environmental regulation $(12 \%$ in the EU-27, 27\% in the UK, 16\% in Turkey, and 20\% in Russia) (EC 2012). Introducing measures against increasing environmental pressures before they become mandatory could constitute a first-mover advantage, thus reducing environmental liability. A significant number of firms voluntarily go beyond environmental regulation (11\% in the EU-28, 13\% in Germany, 9\% in Russia, $16 \%$ in Turkey) (EC 2013), which could improve the firms' corporate image.

\section{Applying the framework to a microeconomic investment project}

The framework is now applied to a microeconomic investment project financed by a multilateral development bank (Table 2). ${ }^{3}$ The investment project comprises a range of energy and material efficiency measures regarding the production of polyvinyl chloride (PVC) plastics.

Not all individual components of the framework can be matched to the investment project, because of its nature and more importantly lacking information. The environmental implications of the investment project are measured in GHG emissions and therefore non-GHG related environmental pressures are not accounted for, in particular local pollution. Furthermore, it is assumed that all material efficiency measures are fully implemented and yield their expected results in the first year after the investment took place. A discount rate of zero is assumed to avoid any mismatch between economic and environmental impacts. ${ }^{4}$ Wherever possible, methods on how to estimate any remaining gaps are proposed.

\footnotetext{
${ }^{3}$ The investment project is presented anonymously to comply with confidentiality agreements.

${ }^{4}$ Future costs and benefits are typically discounted by using a discount factor $\delta$. For economic costs and benefits, an interest rate in the economy is often taken to represent $\delta$ which (in normal economic circumstances) is a positive rate $(\delta>0)$. However, the level of the interest rate is highly debated (e.g. Arrow et al. 1996). For environmental costs and benefits, no universally agreed discount factor exists which is due to the high degree of uncertainty involved in estimating future impacts of GHG emissions (Pindyck 2007). Some apply a range of positive discount rates which illustrates this uncertainty (e.g. U.S. Government 2013). Given the lack of reliable estimates to discount environmental costs and benefits, we chose not to apply any discount rate in order to avoid any mismatch between economic and environmental impacts. Applying discount rates, our results would only change in terms of their level but not in terms of their trend (unless the economic discount rate exceeds the environmental one in our case study by a factor of 583). This means that the year in which the investment yields a positive accumulated net benefit might change, but the overall conclusions drawn from our results are likely to remain valid.
} 
Costs and benefits of a material efficiency investment project

\begin{tabular}{|c|c|c|c|c|}
\hline & \multicolumn{2}{|c|}{ Benefits } & \multicolumn{2}{|c|}{ Costs } \\
\hline & Environmental & Economic & Environmental & Economic \\
\hline 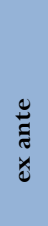 & & $\begin{array}{l}9.3 \text { million } € \text { one-off } \\
590,000 € \text { per year } \\
\text { - includes investment, } \\
\text { operation and maintenance } \\
\text { costs, and cost of ISO } 50001\end{array}$ & $\begin{array}{l}3.7 \text { million } € \text { per year } \\
\text { - includes GHG emissions } \\
\text { from energy and material use } \\
\text { - excludes local pollution, } \\
\text { price of other GHGs besides } \\
\mathrm{CO}_{2} \text {, and health impacts }\end{array}$ & $\begin{array}{l}\text { - no information on costs of } \\
\text { material price volatility, } \\
\text { lock-ins or supply-chain } \\
\text { externalities }\end{array}$ \\
\hline $\begin{array}{l}\vec{b} \\
\vdots \\
\vdots \\
\dot{a}\end{array}$ & $\begin{array}{l}314,000 € \text { per year } \\
\text { - includes GHG emissions } \\
\text { reduction from energy and } \\
\text { material efficiency reduction } \\
\text { - excludes local pollution, } \\
\text { price of other GHGs besides } \\
\mathrm{CO}_{2} \text {, and health impacts }\end{array}$ & $\begin{array}{l}2.42 \text { million } € \text { per year } \\
\text { - includes energy savings and } \\
\text { material recycling } \\
\text { - excludes eco-innovations, } \\
\text { benefits from reduced exposure } \\
\text { to material price volatility, } \\
\text { reputational benefits, reduced } \\
\text { liability }\end{array}$ & $0 €$ & $\begin{array}{l}9.3 \text { million } € \text { one-off } \\
590,000 € \text { per year } \\
\text { - includes investment, } \\
\text { operation and maintenance } \\
\text { costs, and cost of ISO } 50001 \\
\text { - excluding opportunity costs }\end{array}$ \\
\hline
\end{tabular}

Table 2 applies the framework to a microeconomic investment project. The framework distinguishes between two scenarios (ex ante and ex post the investment) and two dimensions (environmental and economic). A price of $24 €$ per tonne of $\mathrm{CO}_{2}$ emissions is assumed, not considering the damages caused by other GHGs.

(i) Environmental costs in the BAU scenario: Ex ante to the investment project, the company consumed approximately 35,000 MWh electricity per year and produced 45,000 tonnes of PVC plastics annually. The GHG emission factors in the firm's country of operation is 0.472 tonnes of $\mathrm{CO}_{2}$ equivalent $\left(\mathrm{tCO}_{2} \mathrm{e}\right)$ per $\mathrm{MWh}$ of electricity and $3.1 \mathrm{tCO}_{2} \mathrm{e}$ per tonne of PVC plastics, which covers the entire life-cycle of PVC plastics (Hammond and Jones 2008). Thus, the firm's GHG emissions are estimated to be $156,000 \mathrm{tCO}_{2}$ e per year. ${ }^{5}$ Monetising the firm's GHG emissions would require a carbon price, for which estimates range between \$10-200 per tonne of $\mathrm{CO}_{2}$ (Pindyck 2013). Following Clements et al. (2013), we assume damages from global warming of $\$ 25$ (around 24€) per tonne of $\mathrm{CO}_{2}$ emission, a conservative figure which neglects other GHGs. This results in environmental costs in the BAU scenario of 3.7 million $€$ per year.

There is no information on potential negative impacts on human health and thus labour productivity for this particular case study. ${ }^{6}$

(ii) Environmental benefits in the BAU scenario: There are no apparent environmental benefits in the BAU scenario.

(iii) Environmental costs from investments in material efficiency: There is no indication for a more than proportional relationship between the efficiency measures and environmental impacts, thus no environmental costs arise.

There is also no information on a potential rebound effect. The efficiency improvements would only imply an environmental cost if they 'backfire'. Since

\footnotetext{
${ }^{5}$ The actual GHG emissions are likely to be slightly lower since the embodied GHG emission for PVC plastics already include the electricity consumed during the production process. However, the GHG emission factor for PVC plastics is a 'conservative' figure since it calculated assuming a best available technology benchmark. Additionally, the figure excludes any environmental pressures that occur at the local level (e.g. local air and water pollution) due to the lack of adequate information.

${ }^{6}$ However, this does not mean that there are no health impacts. For an overview of general environmental and health impacts of PVC, refer to (EC 2004).
} 
consumption decreases in absolute terms, a 'backfiring' rebound effect can be excluded, thus the environmental costs are $0 €$. However, this is likely to change once the firm decides to expand its production as a result of the efficiency gains.

(iv) Environmental benefits from investments in material efficiency: Implementing all efficiency measures are estimated to save $13,068 \mathrm{tCO}_{2} \mathrm{e}$ per year. This is achieved by reducing electricity consumption, substituting electricity supplied by the national grid with own and more efficient electricity production using natural gas, and recycling 800 tonnes PVC plastics per year replacing virgin materials. Applying a carbon price of $24 €$ per tonne of $\mathrm{CO}_{2}$ emissions, we estimate the environmental benefits (i.e. reduced emissions compared to the ex ante emissions) to be $314,000 €$ per year. Such benefits do not comprise environmental benefits at the local level since this information was not collected for the investment project.

Since there is no information on potential negative impacts on human health and thus labour productivity for this particular case study, no benefits from reducing such impacts can be calculated.

(v) Economic costs in the BAU scenario: Prices for electricity and PVC raw materials are volatile, which might impose costs on the firm. With the available information, it is not possible to estimate these costs. One method of filling this gap would be to estimate the firm's willingness to pay in order to have price stability (e.g. Epaulard and Pommeret 2003). Using this methodology would reveal a firm-specific (and subjective) monetary value (OECD 2008).

There is no indication that the firm is subject to lock-ins or supply-chain externalities.

(vi) Economic benefits in the BAU scenario: The investment costs for the firm's efficiency measures amount to a one-off cost of 9 million $€$ and continuous (operation and maintenance) costs of 590,000€ per year.

The firm has already implemented standards for quality (ISO 9001) and environmental management (ISO 14001), and as part of the investment project plans to implement the standard for energy management (ISO 50001), which is estimated to cost 300,000€ (excluding benefits) (Therkelsen et al. 2013). Thus, the economic benefits amount to 9.3 million $€$ and 590,000€ per year, assuming the loan would have been granted to the firm regardless of how it would spend the money.

(vii) Economic costs from investments in material efficiency: The costs for the firm's efficiency measures sum up to a one-off cost of 9.3 million $€$ and yearly costs of $590,000 €$.

Once invested, the firm cannot invest in alternative proposals, assuming that the loan would also be granted for alternative investment appraisals. If the firm is a rational actor, there is no alternative investment yielding higher returns. Since there is no information on potential alternative investment opportunities, the opportunity costs for this project cannot be calculated.

(viii) Economic benefits from investments in material efficiency: The economic benefits sum up to 2.42 million $€$ per year. 1.8 million $€$ per year are energy efficiency measure and 620,000€ per year stem from recycling PVC plastics by reducing the purchasing costs of primary raw materials.

The investment project does not directly incentivise eco-innovations. However, re-investing the efficiency gains could fund eco-innovation activity. Since the firm reduces its consumption, negative effects from prices volatility are reduced. Monetising this benefit cannot be done with the information available, 
but the method of estimating the firm's willingness to pay described above could be a starting point for approximating it (e.g. Epaulard and Pommeret 2003).

The firm's corporate image is likely to improve, especially if customers value the firm's compliance with environmental and managerial standards. Monetising the benefits requires customer surveys to estimate the value customers put on such standards. Estimating reduced environmental and social liability would require an estimate of the probability of damages caused by not increasing efficiency. This estimate can then be multiplied with the compensation to be paid in case of becoming liable to damages, which would calculate the expected benefit of reducing liability by increasing efficiency.

\section{Do material efficiency investments deliver net benefits?}

In the previous section, we applied the cost-benefit framework to a microeconomic investment project. Our results from this case study suggest that there are positive net benefits from investing in material efficiency. Already monetised (i.e. economic) net benefits are achievable after five years. By attributing a monetary value to costs and benefits without market prices, social, i.e. the sum of economic and environmental, net benefits can be reached one year earlier (Table 3). Despite positive economic net benefits of 'inaction' (which assume that the loan would have been granted to the firm regardless of the investment project), there are social net costs associated with 'inaction' after two years. These results demonstrate the nature of material efficiency investments, which require a more comprehensive approach by internalising negative externalities and also considering the cost of 'inaction'.

\begin{tabular}{l|cccccc} 
in 1,000 $€$ & $\mathbf{t}_{\mathbf{0}}$ & $\mathbf{t}_{\mathbf{1}}$ & $\mathbf{t}_{\mathbf{2}}$ & $\mathbf{t}_{\mathbf{3}}$ & $\mathbf{t}_{\mathbf{4}}$ & $\mathbf{t}_{\mathbf{5}}$ \\
\hline economic net benefits of inaction & 9,890 & 10,480 & 11,070 & 11,660 & 12,250 & 12,840 \\
env. net benefits of inaction & $-3,700$ & $-7,400$ & $-11,100$ & $-14,800$ & $-18,500$ & $-22,200$ \\
\hline social net benefits of inaction & 6,190 & 3,080 & -30 & $-3,140$ & $-6,250$ & $-9,360$ \\
\hline \hline economic net benefits of investment & $-7,470$ & $-5,640$ & $-3,810$ & $-1,980$ & -150 & 1,680 \\
env. net benefits of investment & 314 & 628 & 942 & 1,256 & 1,570 & 1,884 \\
\hline social net benefits of investment & $-7,156$ & $-5,012$ & $-2,868$ & -724 & 1,420 & 3,564
\end{tabular}

Table 3 shows the accumulated economic, environmental and social (i.e. the sum of economic and environmental) net benefits in $1,000 €$ in the years after the investment took place $\left(\mathrm{t}_{0}\right)$.

Nevertheless, there are remaining gaps in applying all components of the cost-benefit framework, which often suffers from a lack of information or methods to monetise some costs and benefits. In this regard, an increasing number of initiatives have been introduced, linking businesses to natural capital and developing methods to internalise externalities (WBCSD 2010; KPMG 2014; Natural Capital Coalition 2015). ${ }^{7}$ Additionally, our results are based on several assumptions such as the prices of carbon, electricity, PVC plastics and natural gas, the successful implementation of all efficiency measures, exchange rates, and the GHG emission factors (among others). Generally, whether an investment in material efficiency provides net benefits depends on the expectations about future price levels and volatility, diffusion of technology, future (environmental) regulation, discount rates and the response by competitors (AMEC and Bio IS 2013). Expectations are particularly relevant in the context of material price volatility since volatility both incentivises and disincentivises investments. On the one hand, volatile prices can make the expected payoffs of material efficiency investments uncertain

${ }^{7}$ We would like to thank an anonymous reviewer for pointing out these initiatives. 
(Pindyck 1991). On the other hand, increasing material efficiency can reduce the exposure to the negative impacts of volatile prices, i.e. one way of hedging against volatile prices (Ebrahim et al. 2014). A sensitivity analysis based on all these assumptions, however, goes beyond the scope of this analysis.

Given the apparent benefits from material efficiency investments for our case study, the question arises why such (net) benefits may not always materialise in practice. Besides general risks and uncertainties, investment barriers and market inefficiencies could prevent material efficiency investments or reduce anticipated benefits. Such barriers include information constraints, capacity constraints, financial constraints (i.e. access to finance), uncompetitive market structures, fiscal mismanagement (e.g. subsidies) and general systemic risks and uncertainty (Jordan et al. 2014; Flachenecker and Rentschler 2015).

Overall, our analysis calls for a comprehensive approach to material efficiency investments, taking environmental impacts into account. In order to make the social benefits of material efficiency investments visible, externalities need to be internalised, the cost of 'inaction' needs to be accounted for and robust methods are required to attribute a monetary value to those costs and benefits without market prices. Lastly, more empirical research is necessary to better understand the implications of increasing material efficiency on the environment as well as the economy, in particular on competitiveness.

\section{Conclusions}

This paper introduces a comprehensive cost-benefit framework to assess the viability of investments in material efficiency. The framework goes beyond conventional cost-benefit analyses by considering primary and secondary effects, two scenarios (business-as-usual and scaling up material efficiency) and two dimensions (environmental and economic). The framework is matched to evidence from the existing literature and applied to a microeconomic investment project financed by a multilateral development bank (MDB). Applying the costbenefit framework suggests that material efficiency investments can yield positive net benefits, which further increase when non-monetary dimensions are additionally taken into account. As such, this framework can be used by firms, MDBs and policy makers to assess the viability of individual material efficiency investments as well as identify the scope for policy intervention in achieving higher net benefits from a societal perspective.

This paper calls for a more comprehensive approach towards material efficiency investment appraisals, which go beyond purely commercial consideration by including negative externalities and the cost of 'inaction'. Robust methods are required to adequately monetise costs and benefits without market prices. Lastly, the literature on material efficiency investments provides important insights, but further research is necessary to increase our understanding of the implications of moving towards material efficient economies.

\section{References}

Allwood JM, Ashby MF, Gutowski TG, Worrell E (2011) Material efficiency: A white paper. Resour Conserv Recycl 55:362-381. doi: 10.1016/j.resconrec.2010.11.002

Allwood JM, Cullen JM, Milford RL (2010) Options for achieving a 50\% cut in industrial carbon emissions by 2050. Environ Sci Technol 44:1888-94. doi: 10.1021/es902909k

AMEC, Bio IS (2013) The Opportunities to Business of Improving Resource Efficiency. Report prepared for the European Commission. DG Environment. Brussels, Belgium

Arrow KJ, Cline WR, Maler KG et al. (1996) Intertemporal equity, discounting, and economic efficiency, in: Climatic Change: Economic and Social Dimensions of Climate Change, Second Assessment of the Intergovernmental Panel on Climate Change.

Arthur W (1989) Competing Technologies, Increasing Returns, and Lock-In by Historical Events. Econ J 99:116-131. 
Bahn-Walkowiak B, Bleischwitz R, Distelkamp M, Meyer M (2012) Taxing construction minerals: a contribution to a resource-efficient Europe. Miner Econ 25:29-43. doi: 10.1007/s13563-0120018-9

Barnes W, Gartland M, Stack M (2004) Old habits die hard: path dependency and behavioral lock-in. J Econ Issues 38:371-377.

Barrett J, Scott K (2012) Link between climate change mitigation and resource efficiency: A UK case study. Glob Environ Chang 22:299-307. doi: 10.1016/j.gloenvcha.2011.11.003

Bishop R (1978) Endangered Species and Uncertainty: The Economics of a Safe Minimum Standard. Am J Agric Econ 60:10-18.

Bleischwitz R (2010) International economics of resource productivity - Relevance, measurement, empirical trends, innovation, resource policies. Int Econ Econ Policy 7:227-244. doi: $10.1007 / \mathrm{s} 10368-010-0170-\mathrm{z}$

Bleischwitz R (2012) Towards a Resource Policy - Unleashing Productivity Dynamics and Balancing International Distortions. Miner. Econ. 24

Bringezu S, Schütz H (2013) Economy-wide indicators. Wuppertal Institute. Economy-wide Material Flow Analysis and Indicators.

Bruyn S, Markowska A, de Jong F, Blom M (2009) Resource Productivity, Competitiveness and Environment Policies. Delft, CE Delft.

Calcott P, Walls M (2005) Waste, recycling, and 'Design for Environment': Roles for markets and policy instruments. Resour Energy Econ 27:287-305. doi: 10.1016/j.reseneeco.2005.02.001

Cellini SR, Kee JE (2010) Cost-Effectiveness and Cost-Benefit Analysis. Handb. Pract. Progr. Eval. pp 493-530

Chatham House (2012) Resources Futures. The Royal Institute of International Affairs. London, UK

Clements M, Coady D, Fabrizio M (2013) Energy Subsidy Reform: Lessons and Implications. Int Monet Fund 68.

Distelkamp M, Meyer B, Meyer M (2010) Quantitative und qualitative Analyse der ökonomischen Effekte einer forcierten Ressourceneffizienzstrategie Abschlussbericht zu AP5.

Ebrahim Z, Inderwildi OR, King DA (2014) Macroeconomic impacts of oil price volatility: Mitigation and resilience. Front Energy 8:9-24. doi: 10.1007/s11708-014-0303-0

EC (2011a) Analysis associated with the Roadmap to a Resource Efficient Europe Part I. SEC(2011) 1067 final. Brussels, Belgium

EC (2011b) Analysis associated with the Roadmap to a Resource Efficient Europe Part II. SEC(2011) 1067 final. Brussels, Belgium

EC (2013) SMEs, Resource Efficiency and Green Markets. Flash Eurobarometer 381. Brussels, Belgium

EC (2011c) Attitudes of European entrepreneurs towards eco-innovation. Flash Eurobarometer 315. Brussels, Belgium

EC (2012) SMEs, Resource Efficiency and Green Markets. Flash Eurobarometer 342. Brussels, Belgium

EC (2004) Life Cycle Assessment of PVC and of principal competing materials. Brussels, Belgium

ECSIP Consortium (2013) Treating Waste as a Resource for the EU Industry. Analysis of Various Waste Streams and the Competitiveness of their Client Industries.

EEA (2013) Environmental Pressures from European Consumption and Production - A study in integrated environmental and economic analysis.

Epaulard A, Pommeret A (2003) Recursive utility, endogenous growth, and the welfare cost of volatility. Rev Econ Dyn 6:672-684. doi: 10.1016/S1094-2025(03)00016-4

Fh-ISI, Wuppertal Institute, Arthur D. Little GmbH (2005) Studie zur Konzeption eines Programms für die Steigerung der Materialeffizienz in mittelständischen Unternehmen.

Flachenecker F (2015) Sustainability, Resource Efficiency and Competitiveness An Assessment of Resource Efficiency Policies in the European Union. Bruges Eur. Econ. Res. Pap. 32:

Flachenecker F, Rentschler JE (2015) Investments in Resource Efficiency - Costs and Benefits, Investment Barriers, Intervention Measures. A report prepared for the European Bank for Reconstruction and Development. London, UK

Fried H, Lovell C, Schmidt S (2008) The Measurement of Productive Efficiency and Productivity Change, Chapter 1. doi: 10.1093/acprof

Graedel TE, Allwood J, Birat JP, et al. (2011) What do we know about metal recycling rates? J Ind Ecol 15:355-366. doi: 10.1111/j.1530-9290.2011.00342.x 
Hammond GP, Jones CI (2008) Embodied energy and carbon in construction materials. Proc Inst Civ Eng - Energy 161:87-98. doi: 10.1680/ener.2008.161.2.87

IEA (2010) Energy Technology Perspectives: Scenarios \& Strategies To 2050. Int Energy Agency Publ. doi: $10.1049 /$ et:20060114

Ignatenko O, van Schaik A, Reuter M a. (2008) Recycling system flexibility: the fundamental solution to achieve high energy and material recovery quotas. J Clean Prod 16:432-449. doi: 10.1016/j.jclepro.2006.07.048

IMF (2015) Primary Commodity Price Database. http://www.imf.org/external/np/res/commod/index.aspx

IPCC (2007) Contribution of Working Group III to the Fourth Assessment Report of the Intergovernmental Panel on Climate Change Summary: Summary for Policymakers.

Jordan ND, Lemken T, Liedtke C (2014) Barriers to Resource Efficiency Innovations and Opportunities for Smart Regulations - the Case of Germany. Environ Policy Gov. doi: 10.1002/ eet.1632

KfW (2009) Perspektive Zukunftsfähigkeit - Steigerung der Rohstoff- und Materialeffizienz. Frankfurt, Germany

KPMG (2014) A New Vision of Value - Connecting Corporate and Societal Value Creation. kpmg.com

Meadows D, Goldsmith E, Meadow P (1972) The limits to growth - A Report to The Club of Rome. Universe Books, New York, USA

Meyer B (2011) Macroeconomic modelling of sustainable development and the links between the economy and the environment - ENV.F.1/ETU/2010/0033. Osnabruck, Germany

Natural Capital Coalition (2015) Natural Capital Protocal Principles and Framework. doi: www.naturalcapitalcoalition.org

Nicolli F, Johnstone N, Söderholm P (2012) Resolving failures in recycling markets: the role of technological innovation. Environ Econ Policy Stud 14:261-288. doi: 10.1007/s10018-0120031-9

Oakdene Hollins (2011) The Further Benefits of Business Resource Efficiency.

OECD (2001) Measuring Productivity - OECD Manual - Measurement of aggregate and industry-level productivity growth. Paris, France

OECD (2008) A Study on Methodologies Relevant to the OECD Approach on Sustainable Materials Managment. Paris, France

OECD (2011) Resource Productivity in the G8 and the OECD A Report in the Framework of the Kobe 3R Action Plan. Paris, France.

Perman R, Ma Y, Common M, et al. (2011) Natural Resource and Environmental Economics. Addison Wesley; 4 edition

Pfaff M, Sartorius C (2015) Economy-wide rebound effects for non-energetic raw materials. Ecol Econ 118:132-139. doi: 10.1016/j.ecolecon.2015.07.016

Pindyck RS (1991) Irreversibility, Uncertainty, and Investment. J Econ Lit 29:1110-1148. doi: $10.1007 / \mathrm{s} 11146-007-9087-\mathrm{x}$

Pindyck RS (2007) Uncertainty in Environmental Economics. Review of Environ Econ and Policy 1:4565. doi: $10.1093 / \mathrm{reep} / \mathrm{rem} 002$

Pindyck RS (2013) Climate Change Policy: What Do the Models Tell Us? NBER Work Pap Ser 51:123. doi: $10.1257 /$ jel.51.3.860

Schliephake K, Stevens G, Clay S (2009) Making resources work more efficiently - the importance of supply chain partnerships. J Clean Prod 17:1257-1263. doi: 10.1016/j.jclepro.2009.03.020

Schmidt M, Schneider M (2010) Kosteneinsparungen durch Ressourceneffizienz in produzierenden Unternehmen. Umweltwirtschaftsforum 18:153-164. doi: 10.1007/s00550-010-0182-8

Schröter M, Lerch C, Jäger A (2011) Materialeffizienz in der Produktion: Einsparpotenziale und Verbreitung von Konzepten zur Materialeinsparung im Verarbeitenden Gewerbe. FraunhoferInstitut für Syst. und Innov. ISI

Sorrell S (2007) The Rebound Effect: an assessment of the evidence for economy-wide energy savings from improved energy efficiency. UK Energy Research Center.

Statistisches Bundesamt (2011) Statistisches Jahrbuch 2011. Wiesbaden, Germany.

Steinberger JK, Krausmann F, Eisenmenger N (2010) Global patterns of materials use: A socioeconomic and geophysical analysis. Ecol Econ 69:1148-1158. doi: 10.1016/j.ecolecon.2009.12.009

Therkelsen P, McKane A, Sabouni R, et al. (2013) Assessing the Costs and Benefits of the Superior 
Energy Performance Program. 2013 ACEEE Summer Study Energy Effic Ind 14.

UNEP (2014) Sustainable Consumption and Production - Targets and Indicators. UNEP Discussion Paper.

UNEP IRP (2010) Assessing the Environmental Impacts of Consumption and Production - Priority Products and Materials. A Report of the Working Group on the Environmental Impacts of Products and Materials to the International Panel for Sustainable Resource Management. Hertwich, E., van der Voet, E., Suh, S., Tukker, A., Huijbregts M., Kazmierczyk, P., Lenzen, M., McNeely, J., Moriguchi, Y.

UNEP IRP (2013) Environmental Risks and Challenges of Anthropogenic Metals Flows and Cycles. A Report of the Working Group on the Global Metal Flows to the International Resource Panel. van der Voet, E.; Salminen, R.; Eckelman, M.; Mudd, G.; Norgate, T.; Hischier, R.

U.S. Government (2013) Technical Update of the Social Cost of Carbon for Regulatory Impact Analysis Under Executive Order 12866 - Interagency Working Group on Social Cost of Carbon. Washington, DC, USA

Valiante D, Egenhofer C (2013) Price Formation in Commodities Markets: Financialisation and Beyond. Report of an ECMI/CEPS Task Force. Brussels, Belgium

Walz R (2011) Employment and structural impacts of material efficiency strategies: results from five case studies. J Clean Prod 19:805-815. doi: 10.1016/j.jclepro.2010.06.023

WBCSD (2010) Vision 2050 - the New Agenda for Business. doi: 10.1111/j.1530-9290.2009.00117.x

Wilting H, Hanemaaijer A (2014) Share of raw material costs in total production costs. PBL Netherlands Environmental Assessment Agency. Amsterdam, Netherlands 